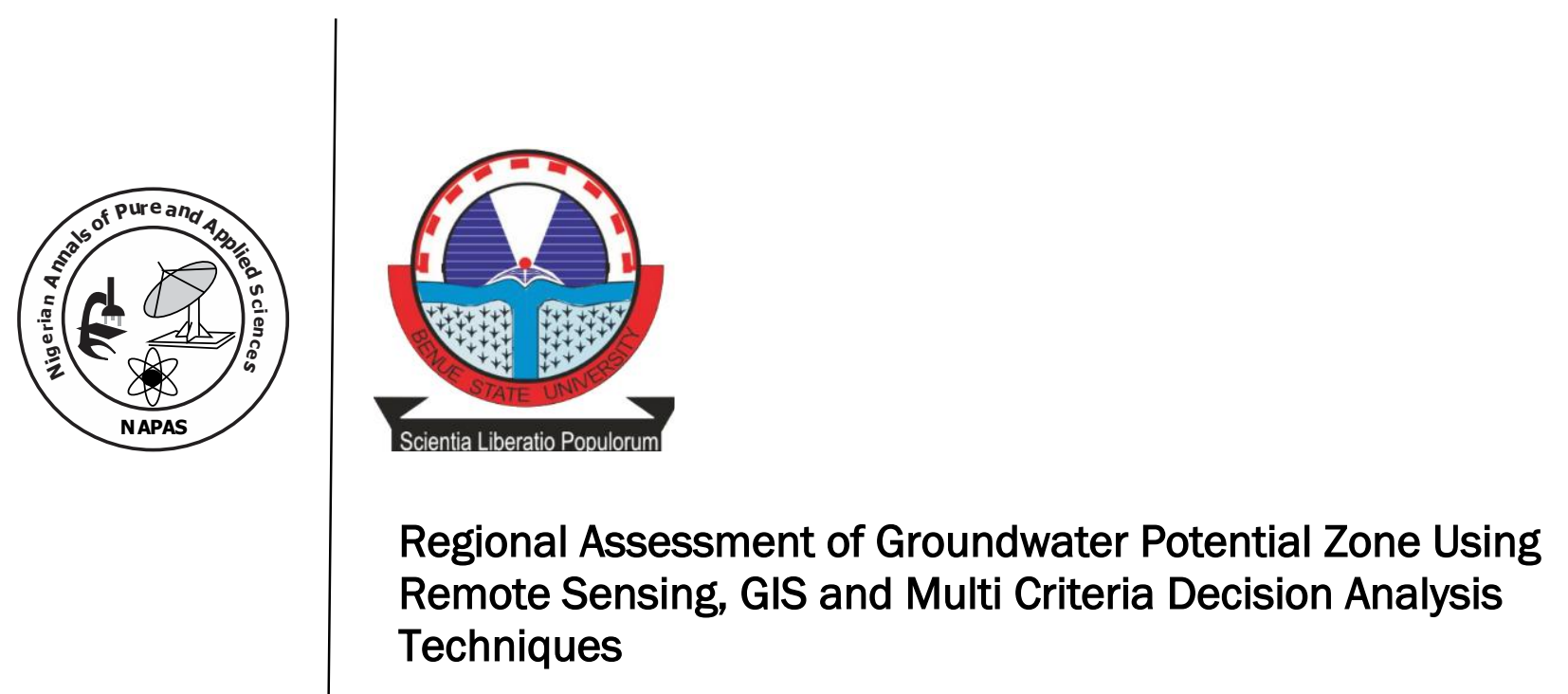

\title{
Ejepu, J.S.
}

Department of Geology, School of Physical Sciences, Federal University of Technology, Minna, Nigeria.

Corresponding author: ejepu.jude@futminna.edu.ng

\begin{abstract}
The growing demand for freshwater for domestic and industrial purposes is a current challenge in the Upper Niger River Basin Development Authority area. Consequently, there is heavy demand for groundwater resources to meet this need. This challenge has worsened due to the nonincorporation of integrated methods in groundwater exploration campaigns. Innovative scientific principles and quantitative assessment of groundwater resources are required for sustainable and proper management of the resources. Therefore, the objective of this paper is to exploit the potential application of remote sensing, Geographic Information System (GIS), and Multi-Criteria Decision Analysis (MCDA) techniques in mapping groundwater potential zones. To achieve this, seven factors deemed to have significant control over the occurrence and movement of groundwater viz. geology, lineament density, slope, drainage density, rainfall, land-use/land cover, and soil class were produced. These factors were assigned weights and normalized with respect to their relative contributions to groundwater occurrence using the Analytic Hierarchy Process (AHP). This resulted in groundwater potential zones that have been classified into four: Very good, Good, Moderate and Poor representing 7\%, 27\%, 43\%, and 23\% respectively. This result represents groundwater potential in the area and should be used as a preliminary reference in selecting prospective sites for detailed groundwater resource exploitation.
\end{abstract}

Keywords: Groundwater potential zones; Multi-Criteria Decision Analysis, Analytic Hierarchy Process, Geographic Information System, Remote Sensing. 


\section{Introduction}

Nigeria is faced with increasing demands for water resources due to the high population growth rate and growing prosperity. Groundwater has been employed to bridge the ever-increasing demand for freshwater for domestic and industrial purposes. Regional groundwater exploration surveys in both sedimentary and crystalline basement terrains are usually targeted areas having requisite porosities and permeabilities, weathering of considerable thickness, and/or where fracturing and jointing are preponderant (Chandra et al., 2019).

Because of the high failure rate of borehole development in these terrains, an attempt has been made by this study to delineate areas where detailed hydrogeological studies may be conducted to site productive boreholes. Fractured crystalline rock units are the major target in regional groundwater exploration surveys in basement terrains. These fractures constitute secondary porosities that endow crystalline rocks with aquifer attributes. Traditional geological field mapping methods employed in regional hydrogeological mapping can be time-inefficient and limited in scope and coverage. This presents itself in the form of environmental issues including dense vegetation, rugged topography and local social conflicts (Sander, 2006; Ejepu et al., 2017).

Remote sensing techniques circumvent environment-related limitations to provide time-effective capture of attributes that directly reveal regional geological structures. One of such attributes is lineament. Lineaments are readily observable indication of structural discontinuities and trends, because of the common fairly high correlation between structures delineated in the field and lineaments mapped with remote sensing technologies (Díaz-Alcaide \& Martínez-Santos, 2019).

This study has been conceptualised to support the mandate of the River Basin Development Authorities in Nigeria. Eleven river basin development authorities were established in 1961 to ensure that inland water resources in Nigeria are effectively exploited. These river basin development authorities have similar functions and are evenly distributed along river basins of Nigeria.
In Nigeria, river basin development authorities have designated functions which include; irrigation, water supply infrastructure (construction and management) for example, reservoir, dams, borehole. Others include fishery, pollution control among others (Ezenweani, 2017).

Communities located within Basement Complex terrains usually suffer acute potable water challenges arising from the complexity of the hydrogeological setting of the terrains. Poor success rates in water borehole development in Basement Complex regions have been attributed to the non-integration of hydrogeological concepts into anomaly interpretations in borehole siting (Titus et al., 2009).

This research aims to delineate hydrogeologically significant groundwater potential zones in the area via the exploitation of synergy in integrated satellite and geological datasets. This will help in drastically minimising borehole development failure rates in the region. Other ancillary datasets will be derived from the processing of satellite data and other datasets that are freely available on the web.

\section{Study Area}

The study area is situated entirely within Niger State, Kaduna State and the Federal Capital Territory of Nigeria. It is bounded by latitudes $8^{\circ}$ and $11.5{ }^{\circ} \mathrm{N}$ and longitudes $3^{\circ}$ and $9^{\circ} \mathrm{E}$ and covers an area of about $125,000 \mathrm{~km}^{2}$. The region is strongly dissected by three river systems. River Gurara and River Usuma join to form River Kaduna which is a tributary of River Niger in the south. Major tributaries joining River Kaduna along its course include the Mariga, the Tubo, Sarkin Pawa, and Galma (Dan-Hassan, 2016).

In the areas underlain by metasedimentary rocks, the river valleys are narrow and are controlled by the foliations and joints. Areas underlain by granitic rocks have the river generally developing broad valleys. An exception to this is the Shiroro gorge where the river Kaduna which flows north-south is diverted by an NW-SE fracture system into the westward direction of the flow of the smaller River Dinya. The gorge has been exploited for the Shiroro hydroelectric project. The dam axis lies across the gorge and the Shiroro Lake now 
covers large parts in the north-eastern corner of the area. In general, most of the streams in the areas by granitic rocks appear to be controlled by fractures. There is a distinct change in the topography between areas underlain by basement and sedimentary rocks. Whereas, basement topography is generally rugged the sedimentary terrain consists of retative1y smooth-rolling country with inselbergs (DanHassan, 2016).

The area which lies within the Guinea Savanna Ecological Zone is characterised by a decreasing trend of the density of trees and other plants towards its northern part. The climate is the tropical wet and dry type. The wet season lasts from April through to mid-October with a peak in August; while the dry season extends from midOctober of one calendar year to April the next year. The annual average rainfall in the area range from is $1300 \mathrm{~mm}$ to $1700 \mathrm{~mm}$ (SRP, 2020). The annual rainfall is concentrated in the rainy season during which about $80 \%$ of the rain falls. Seasonal variation in rainfall is directly influenced by the interaction of relative warm and moist tropical maritime (mT) air mass and the dry and stable tropical continental (cT) airmass that originates from the Sahara Desert. This also is associated with the dry, cool and dusty North-East Trade Winds known as Harmattan. The mean annual temperature of the area ranges between $27^{\circ} \mathrm{C}$ in the south and $22^{\circ} \mathrm{C}$ in the northeast. The mean atmospheric relative humidity range between $70-90 \%$ and 25 $30 \%$ for the rainy and dry seasons respectively. The highest amount of evaporation occurs during the dry season. Soils of the study area are typically ferruginous soils which form reddish-brown to reddish-yellow colours. These are derived from granite, gneisses parent materials, also from Aeolian and many sedimentary deposits.

The lithology of the area is predominantly igneous and metasedimentary rocks of the Nigerian Basement Complex consisting of biotite gneisses and older granites; but in the south-eastern part, younger granites and batholiths predominate. The Zuma rock at the boundary of the FCT and Niger State is an inselberg that stands very conspicuously in the terrain. This inselberg, landscape and extensive plains found between hills, dominate the other parts of the FCT.

Further analysis of the geology of the study area reveal that Basement rocks cover about $85 \%$ of the land surface and sedimentary rocks cover about $15 \%$ of the terrain in the southwestern (Figure 1).

Major lithologic units found are:

The Older granites (b) The Metasediments (schist, phyllite and quartzite) (c) The Migmatite-Gneiss Complex (d) The Nupe Sandstones of the Bida Basin (Rahaman et al., 1988; Ajibade, 1989).

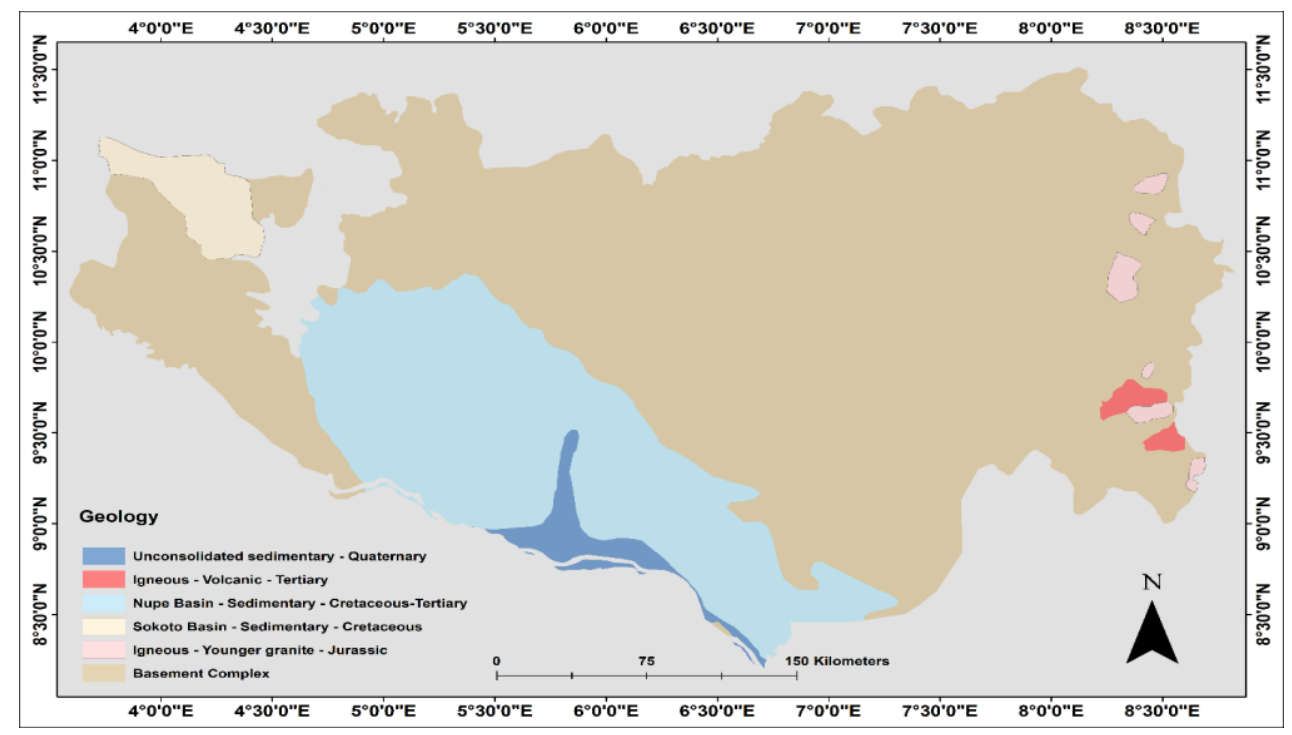

Figure 1: Geologic map of the study area. (Source: Groundwater Atlas of Africa. http://www.geokniga.org/bookfiles/geokniga-geological-atlas-africa.pdf). 


\section{Materials and Methods}

Publicly available datasets on the web were also used for this research. These include: Geological map provided by the Africa Groundwater Literature Archive (http://www.bgs.ac.uk/africagroundwateratlas/ index.cfm); Land-use/ Land cover map provided by the FAO GeoNetwork (http://www.fao.org/geonetwork/srv/en/resour ces.get?id=37204\&fname=nga_gc adg.zip\&a ccess=private); rainfall data provided by the Tropical Rainfall Measuring Mission (https://climatedataguide.ucar.edu/climatedata/trmm-tropical-rainfall-measuring-

mission); digital soil map extracted from Digital soil map of the world (http://www.fao.org/soils-portal/soilsurvey/soil-maps-and-databases/faounescosoil-map-of-the-world/en/) and Shuttle Radar Topographic Mission Digital Elevation Model (SRTM DEM) datasets downloaded from https://dwtkns.com/srtm30;

The geological, land-use/land cover and digital soil maps were properly digitised and georeferenced to be used as thematic maps for reclassification and GIS modelling. The historical rainfall data of 20 years (2001-2019) of the study area was gridded using the inverse distance weighting method to produce the rainfall map of the study area. The processing of SRTM DEM was performed to produce derivative thematic maps that reveal anomalies that are employed in delineating features and aquifers that may impact the groundwater flow and accumulation.

Image processing for $30 \mathrm{~m}$ resolution SRTM DEM was performed using the ArcGIS software to produce thematic layers that included geomorphology, lineament and slope maps. Drainage networks were extracted using the spatial analyst tool of ArcGIS. Drainage density map delineation was carried out by dividing the study area into micro-watersheds using standard published methods. The intersection of mini-watersheds and drainage lines was used for drainage density calculation for each of the mini-watersheds. This is expressed in terms of the length of channels per unit area $\left(\mathrm{km} / \mathrm{km}^{2}\right)$ using a search radius of 2 $\mathrm{km}$. Larger search radii gave rise to drainage densities that are not representative of the drainage networks in the area compared with a published topographic map of the region. The derived drainage density values were reclassified to produce a drainage density map of the study area.

Hillshade representations of SRTM DEM using various sun elevation and illumination angles perpendicular to the prominent structural orientations in the region were selected to enhance the linear features. Lineaments were digitized from the hillshade representations to represent surface lineaments. Subsequently, a lineament density map was created using the line density tool of ArcGIS with a search radius of $1 \mathrm{~km}$.

Thematic layers of Geology, Lineament Density, Slope, Drainage Density, Rainfall, Land-use/Land cover and Soil map were assigned weights using Analytic Hierarchy Process (AHP) software according to their importance in groundwater availability (Goepel, 2019). Thereafter, these thematic layers were reclassified to a common scale of 1 to 4 by intervals of 1 , called scale values for the weighted overlay operation. The ArcGIS Weighted Overlay tool was used to generate the groundwater potential zone of the area (Esri Inc., 2019).

\section{RESULTS AND DISCUSSION \\ Deterministic factors for groundwater occurrence and movements Lithology}

Lithology plays an important role in the occurrence and distribution of groundwater since it is the controlling factor of infiltration rate and flow (Wirth et al., 2020; Adelana et al., 2008; Tijani et al., 2018). The geological map (Figure 1) of the study area reveals the presence of lithology with a range of geological timescale, namely, Upper Proterozoic, Precambrian, Liberian (ca $2800 \mathrm{Ma}$ ) to Pan African (ca $600 \mathrm{Ma}$ ). These rocks occupy an estimated area of $73 \%$. Jurassic (2\%), Cretaceous $(20 \%)$ Tertiary and Quaternary $(5 \%)$. Precambrian lithology of the area is mainly underlain by metamorphic rocks and is considered as low to moderate yielding regional aquifers (Adelana et al., 2008); nevertheless, regolith and fractures are the main groundwater holding and transmitting 
media in a metamorphic terrain (Ejepu et al., 2018).

Cretaceous and Tertiary sediments have better productivity because they have intergranular permeability and can have extensive aquifers (Adelana et al., 2008). The quaternary sediments are made up of alluvium (clays, sands, silts, and river gravel (Table 1). The alluvium has good potential because they are recent deposits and have better permeability and groundwater productivity (Tijani et al., 2018). If fractured, quaternary volcanic could yield a good amount of water. The weight is therefore assigned according to the aforementioned characteristics of the hydrogeological units.

Table 1. Characteristic features of lithological groups in the Upper Niger River Basin Development Authority area (source: Modified from Tijani et al., 2018).

Table 1. Characteristic features of lithological groups in the Upper Niger River Basin Development Authority area

\begin{tabular}{|c|c|c|}
\hline Key Formations & Period & Lithology \\
\hline & & Unconsolidated \\
\hline Alluvium & Quaternary & $\begin{array}{l}\text { Deposits vary in thickness and lithology, with sands, } \\
\text { gravels, silt and clay all present in varying proportions. } \\
\text { These occur along the main river valley sand are thickest } \\
\text { (15 - } 30 \mathrm{~m} \text { thick) in valleys associated with the rivers } \\
\text { Niger and Benue (Adelana et al. 2008). } \\
\text { Sokoto Basin - Sedimentary (Iullemeden) }\end{array}$ \\
\hline
\end{tabular}

Structure

Sokoto Group

(Gwandu,

Kalambaina and

Dange

formations)

Nupe, Patti and

Lokoja

Sandstones

Cretaceous

\section{Niger}

Nigeria's Sokoto Basin represents the south-eastern part of the Iullemmeden basin, which stretches across parts of Mali, Niger, Benin and into northwest Nigeria. The Tertiary rocks of the Sokoto Basin are mostly interbedded sandstones, clay and some limestone (Pavelic et al. 2012). The Gwandu Formation (of Eocene-Miocene age) crops out in the west of the Sokoto Basin and comprises interbedded semi-consolidated sand and clay. It unconformably overlies the Kalambaina Formation in the north and centre of the basin (Adelana et al.2008).

The Kalambaina Formation consists of clayey limestone with modular crystalline limestone, and is underlain by the Dange Formation, a marine clay shale. The Kalambaina and Dange Formations are collectively known as the Sokoto Group and are of Paleocene age (Adelana et al. 2008).

Nupe Basin - Sedimentary

The Nupe Basin is alternatively known as the Bida or The basin contains largely continental sandstones, siltstones,

claystones and conglomerates (Adelana et al, 2008).

Igneous - Younger granites

The total thickness of the Sokoto Basin is over $1250 \mathrm{~m}$

.

Arcuate to circular intrusions forming ring-like complexes.

Precambrian Basement Complex 


\begin{tabular}{|c|c|c|c|}
\hline $\begin{array}{l}\text { Migmatite- } \\
\text { Gneiss Complex } \\
\text { (quartzites, } \\
\text { amphibolites, } \\
\text { marble) }\end{array}$ & $\begin{array}{l}\text { Liberian (ca } \\
2800 \mathrm{Ma} \text { ) to } \\
\text { Pan African } \\
\text { (ca } 600 \mathrm{Ma})\end{array}$ & $\begin{array}{l}\text { These rocks are found in the north-central area of Nigeria, } \\
\text { including the Jos Plateau and in the southwest of Nigeria. } \\
\text { They comprise gneisses, migmatites, granites, schists, } \\
\text { phyllites and quartzites (Adelana et al. 2008). } \\
\text { Metamorphism is in the amphibolites facies range. }\end{array}$ & \\
\hline Schist belt & Precambrian & $\begin{array}{l}\text { Schist belts, comprising phyllites, schists, quartzites and } \\
\text { banded iron formations, found in north-western Nigeria. }\end{array}$ & Folds \\
\hline Older Granites & $\begin{array}{l}\text { Upper } \\
\text { Proterozoic }\end{array}$ & $\begin{array}{l}\text { Intruded into the migmatite-gneiss complex and the schist } \\
\text { belts. }\end{array}$ & \\
\hline
\end{tabular}

\section{Lineaments and lineaments density}

The lineaments delineated from the SRTM

DEM data represented surface lineaments. However, there has been a high-level correlation between lineaments extracted from the surface and geological lineaments delineated using gravity and aeromagnetic datasets (Ejepu et al., 2017; Elmahdy $\&$ Mohamed, 2015). Geological lineaments are the manifestation at the earth's surface of deeper geological structures (faults and fractures that have obvious displacement, ruptures that have no significant fracture displacement) (Han et al., 2018). Lineaments have been applied in various aspects. For example, it has been applied in the distribution of minerals (Ejepu et al., 2018; Bahiru
\& Woldai, 2016), in regional groundwater exploration surveys (Ejepu et al., 2017; Magesh et al., 2012). Furthermore, it has been used to determine the potential areas for geothermal resources, earthquakes (Elmahdy \& Mohamed, 2015) and geomorphology. Moreover, identification of the weathered zones from the lineament density map is useful in groundwater potential studies. Areas with high lineament density (Figure 2) have been inferred as zones that denote good groundwater potential zones. Hence, high lineament zones in the reclassified maps have been assigned higher weights. The distribution of lineament densities has been classified into four viz: $0-0.2,0.21-0.5,0.51-0.8$ and $0.81-1.40$ $\mathrm{km} / \mathrm{km}^{2}$.

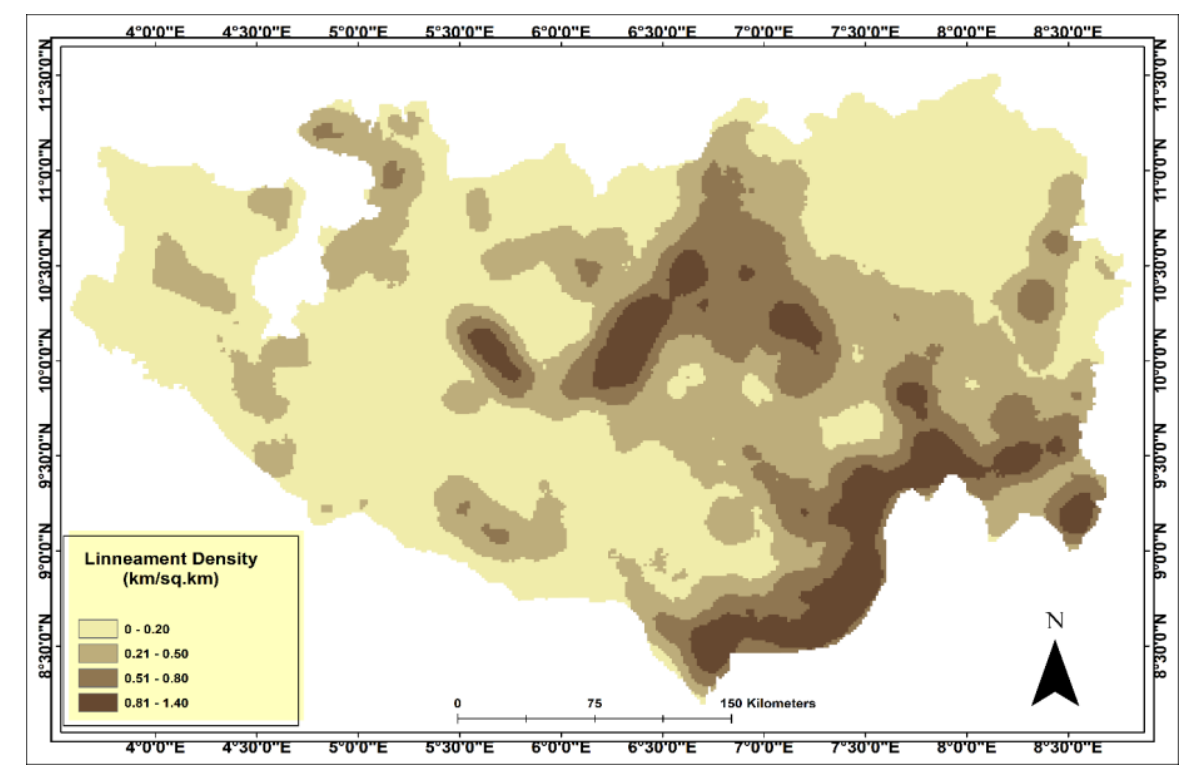

Figure 2: Lineament Density map of the study area.

\section{Slope}

The slope of an area plays a fundamental role in recharge rates and mechanisms of aquifers, thus, indicating good groundwater prospectivity of an area. In a typical Basement Complex terrain, there usually exist a wide range and distribution of slope values. This is one of the primary reasons why the groundwater potential of these terrains varies significantly even at short distances. Where low slope values are mapped, surface runoff is low, thus, allowing for more time for infiltration of rainwater. Conversely, where high slope values are mapped, runoff is usually 
high and this shortens residence times for infiltration and recharge.

In the reclassification of slope angle thematic map (Figure 3), low slope angle values were assigned higher weights while higher slope angles were assigned lower weights. This is because higher slope angles impact negatively on infiltration and groundwater recharge (Rukundo \& Doğan, 2019; Conrad \& Adams, 2007).

\section{Drainage density}

The drainage system of the area exhibits varied drainage systems typical of a sedimentary crystalline basement terrain. The spatial distribution of drainage density is shown in (Figure 4). The area has a moderately dense drainage system with values ranging from $0.01 \mathrm{~km} / \mathrm{km}^{2}$ to $0.5 \mathrm{~km} / \mathrm{km}^{2}$. The spatial distribution of drainage densities shows no particular trend. However, higher drainage densities are found concentrated in uplands and bare surfaces where surface water runoff is high. High drainage density values usually mean that recharge and percolation into the subsurface are low (Mogaji, 2016). Therefore, the drainage density thematic map was assigned a low weight because of its minimal contribution to the groundwater potential in the area.

\section{Rainfall}

Rainfall is one of the important factors to delineate groundwater potential zones especially in regional groundwater exploration campaigns (Ngene et al., 2019). In fact, it is the main source of natural recharge that develops groundwater resources. As shown in Figure 5, the mean annual rainfall ranges from $600-$ $1700 \mathrm{~mm} /$ year. Since the amount of rainfall is an important hydrogeological parameter, playing a significant role in infiltration, a higher weight was given to higher rainfall rate classes (Tolche, 2020).

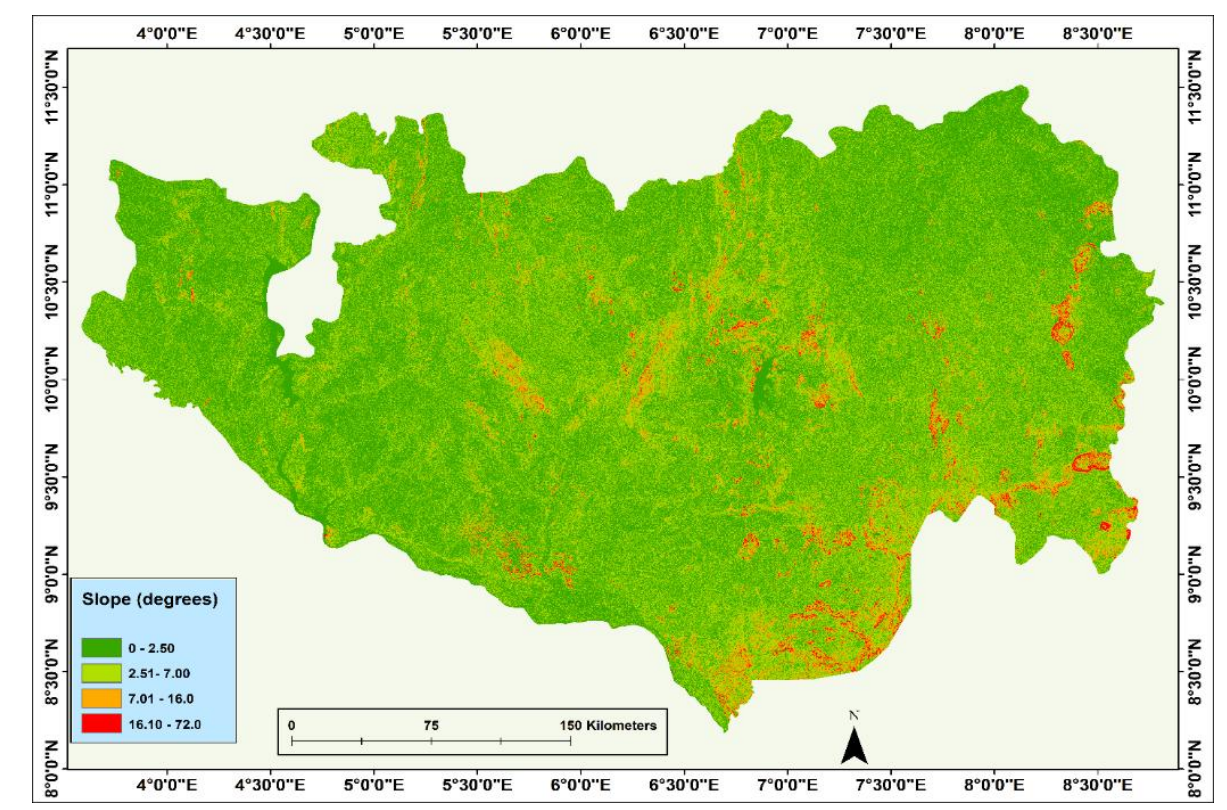

Figure 3: Slope map of the study area. 


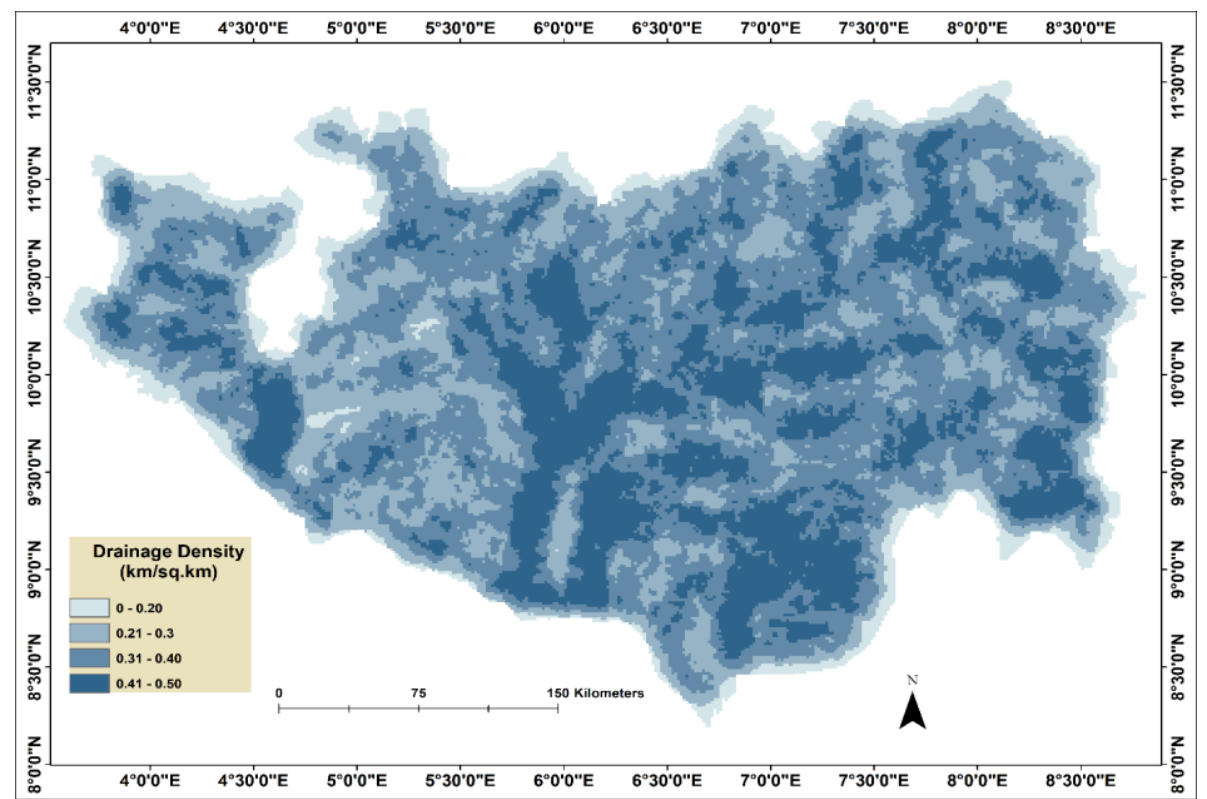

Figure 4: Drainage density map of the study area.

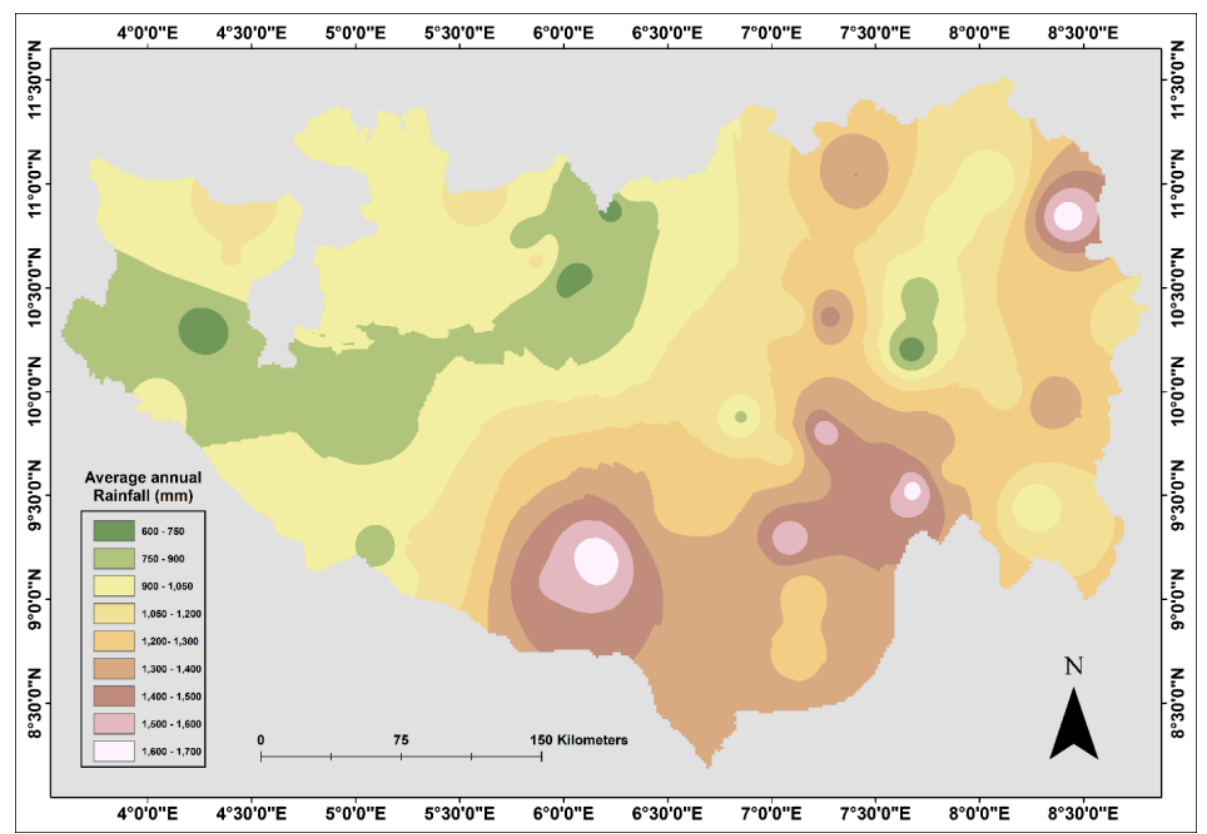

Figure 5: Rainfall map of the study area. (Source: Tropical Rainfall Measuring Mission, 2020).

\section{Land-use land cover (LULC)}

LULC includes the distribution of residential areas, waterbody, and vegetation cover within a certain area. It is an important factor affecting groundwater recharge, groundwater occurrence, and availability (Hussein et al., 2016; Kumar et al., 2016; Pande et al., 2017; Yeh et al., 2016).

The UN Land Cover Classification System provided a valuable universal land cover language for building land cover legends and comparing existing legends (Homer et al., 2015). Additionally, it simplifies the process of harmonization in which the similarities between existing definitions of different datasets are emphasized and inconsistencies reduced. This was integrated with the general approach proposed by FAO with LCCS and thus created the possibility to create a set of consistent rules and in a variety of different conditions. This solution meets the requirements of international comparability and allows unambiguous translation into the standard land cover nomenclatures currently used. It allows also further coherent developments of disaggregated nomenclature 
classes, fit for particular conditions (SEEA, 2012). This was the classification adopted in the production of the land cover maps (Figure $6)$.

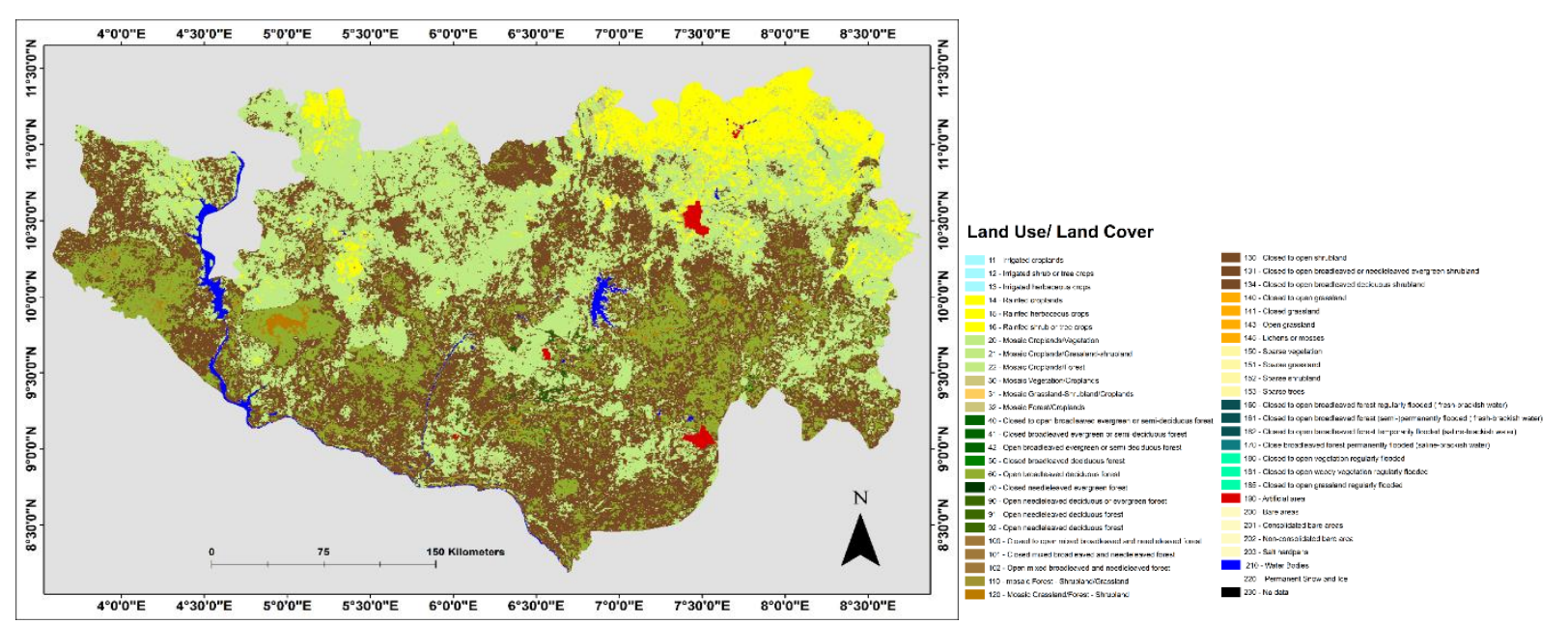

Figure 6: Land cover map of the study area. (Source: European Space Agency Globe Cover 2.3, 2009).

\section{Soils}

Eight soil classes distributed across the study area have been delineated. These include Acrisols, Cambisols, Gelysols, Lithosols, Fluvisols, Luvisols, Nitosols and Planosol (Figure 7). Weights are assigned subjectively to each soil unit after taking into account the type of soil and its water- holding capacity.
Soils, such as Lithosols and Fluvisols have good water-holding capacities and have been given higher weighting scores. Cambisols, Nitosols and Planosols have moderate waterholding capacities. Luvisols, Gleysols and Acrisols were deemed to have poor water holding capacities. These were consequently assigned lower score ratings.

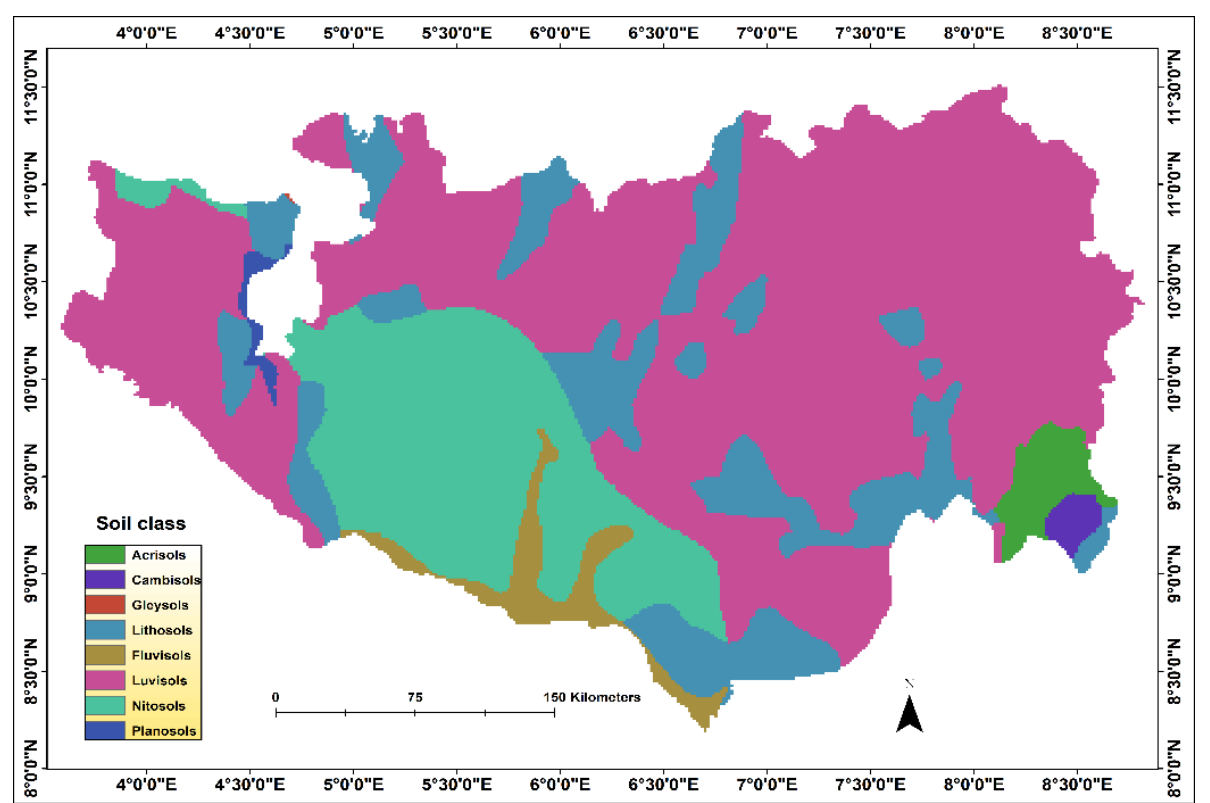

Figure 7: Soil map of the study area. (Source: http://www.fao.org/soils-portal/data-hub/soil-mapsand-databases/en/).

\section{GIS Modelling}

The suitable weights to themes and their features are assigned and then normalized by using an Analytic Hierarchy Process
(AHP)-Multi-Criteria Decision Analysis (MCDA) technique (Figure 8). All themes are integrated into GIS for generating a Groundwater Potential Zone (GPZ) map 
(Figure 9). Four groundwater potential zones have been delineated (Very Good, Good, Moderate and Poor. Their spatial distributions are shown in Figure 9. Very good to good zones are mapped in areas where the lithology mostly exhibits primary porosities (sedimentary sequences in the southwest) and in areas of high lineament and low drainage densities. This emphasises the importance of lithology, lineaments and geomorphological units that favour groundwater accumulation in groundwater investigations (Kumar \& Parma, 2019).

Areas that have been mapped to have good to moderate groundwater prospectivity are attributed to favourable combinations of lithology and geomorphology. The poor groundwater potential zones are spatially distributed mainly along ridges and other topographically high regions and to a certain extent, zones with low lineament density. Metasedimentary rocks such as migmatites and gneisses are mapped as areas with moderate groundwater potential zones. The alluvium that lies at the south-western portion of the map with the sedimentary rocks in the mid-western part of the area has very good to good groundwater potential. The most promising targets have been mapped in the alluvium and sedimentary rocks which intersect areas with dense lineaments.

\section{Conclusions}

This study aimed at developing a costeffective methodology to evaluate groundwater prospects for a basin/sub-basin using geospatial modelling and multicriteria decision analysis technique under limited ground data conditions. The methodology is demonstrated through a case study of the areas covered by the Upper Niger River Basin Development authority comprising of Niger and Kaduna States and the Federal Capital Territory. Seven themes influencing the occurrence of groundwater are integrated to delineate suitable groundwater potential zones.

\section{Priorities}

These are the resulting weights for the criteria based on your pairwise comparisons:

\begin{tabular}{|c|c|c|c|c|c|}
\hline \multicolumn{2}{|c|}{ Cat } & Priority & Rank & $(+)$ & $(-)$ \\
\hline 1 & Geology & $38.5 \%$ & 1 & $15.6 \%$ & $15.6 \%$ \\
\hline 2 & $\begin{array}{r}\text { Lineament } \\
\text { Density }\end{array}$ & $24.6 \%$ & 2 & $7.5 \%$ & $7.5 \%$ \\
\hline 3 & Slope & $11.7 \%$ & 3 & $2.9 \%$ & $2.9 \%$ \\
\hline 4 & $\begin{array}{r}\text { Drainage } \\
\text { Density }\end{array}$ & $6.1 \%$ & 6 & $1.6 \%$ & $1.6 \%$ \\
\hline 5 & Rainfall & $8.2 \%$ & 4 & $2.4 \%$ & $2.4 \%$ \\
\hline 6 & LULC & $6.7 \%$ & 5 & $1.8 \%$ & $1.8 \%$ \\
\hline 7 & Soils & $4.2 \%$ & 7 & $1.5 \%$ & $1.5 \%$ \\
\hline
\end{tabular}

Number of comparisons $=21$ Consistency Ratio CR $=3.5 \%$

\section{Decision Matrix}

The resulting weights are based on the principal eigenvector of the decision matrix:

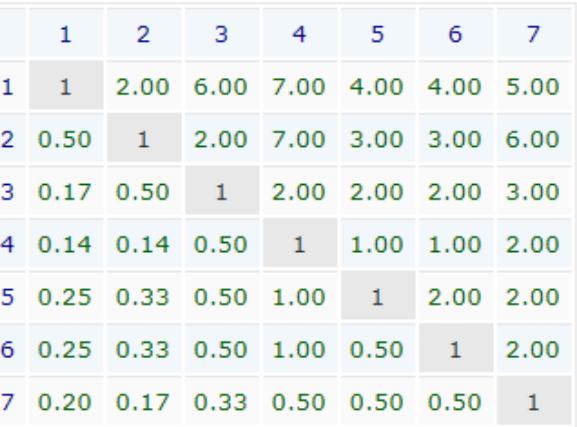

Principal eigen value $=7.282$

Eigenvector solution: 4 iterations, delta $=8.6 \mathrm{E}-8$

Figure 8: Pairwise comparisons used to calculate thematic priorities using the Analytic Hierarchy Process. 


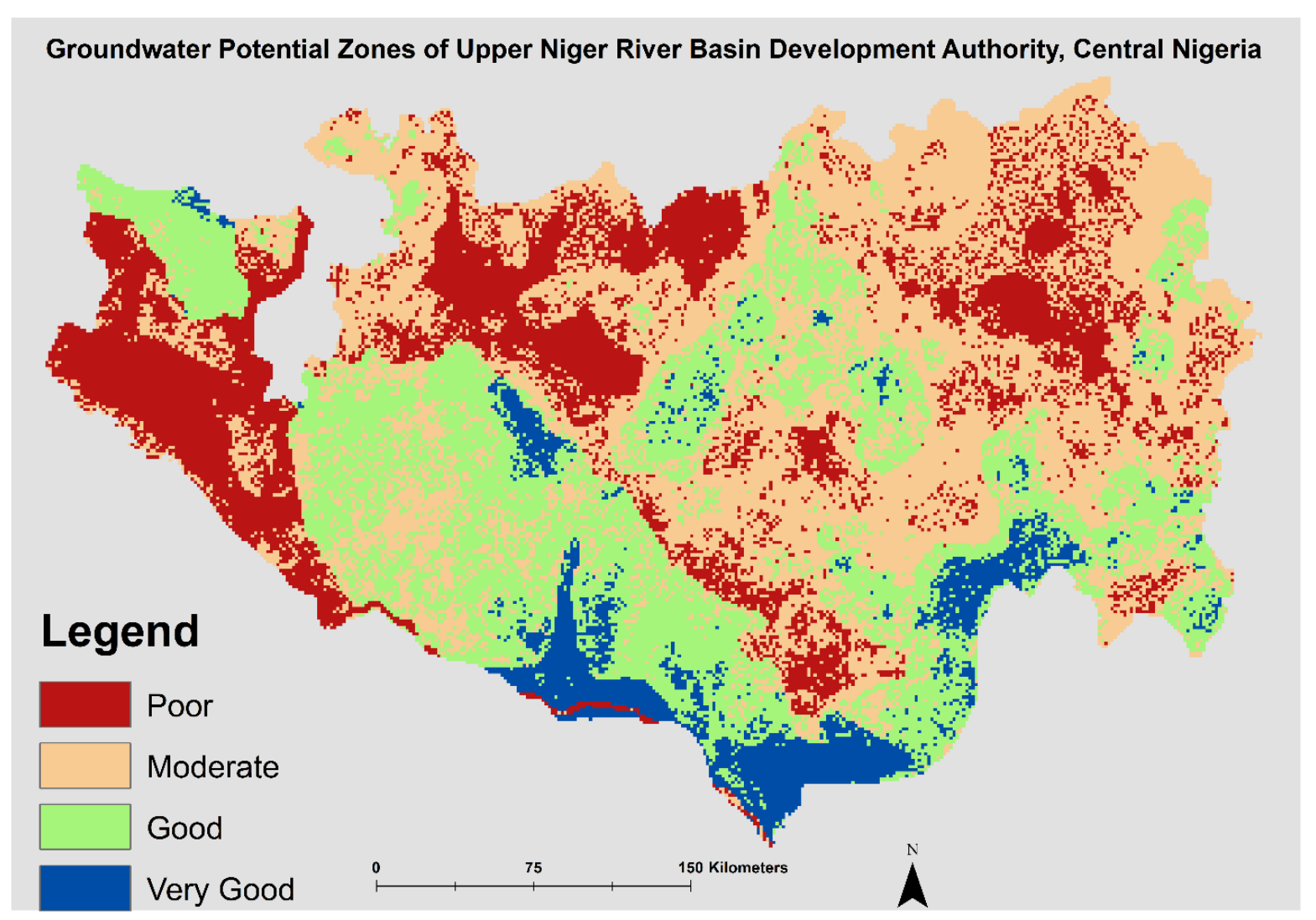

Figure 9: Groundwater potential zone map of the study area.

The following conclusions have been drawn based on the results of this study:

i. Integration of geospatial modelling and MCDA delineated "very good," "good", "moderate" and "poor" zones of groundwater potential representing $7 \%$, $27 \%, 43 \%$, and $23 \%$ of the area respectively.

ii. The flow and accumulation of groundwater are fundamentally controlled by lithology, lineaments, and slope revealed from GIS analyses and field investigations. In Basement Complex terrains, bedrock fractures and intense fracturing control groundwater flow and storage.

iii. The groundwater potential model derived through the integration of thematic maps demonstrates the hydrogeological significance of structure, lithology, and landform types.

This study demonstrated that the multicriteria decision analysis technique can be successfully integrated with remote sensing and geographical information system techniques for a largely accurate and costeffective assessment of groundwater potential under the limited data-availability conditions. The methodology and results obtained in this study can be easily adapted for sustainable planning, development, and management of the precious groundwater resources in other datascarce regions of the developing nations.

The validation of groundwater potential is needed as some of the zones may not accurately reflect ground conditions. It is challenging and hence, a major limitation of this study. Nonetheless, the expected advantages of this method may influence the development of policies, guidelines and future strategies for monitoring the groundwater potential at frequent intervals for balancing the extraction and recharge capacity of aquifers in water scarce regions of the country. Also, informed selection of optimal sites, minimal groundwater survey costs, improved borehole drilling success rates, and subsequently an increased borehole yields are the attendant gains of this integrated study. 


\section{References}

Adelana, S., Olasehinde, P., Bale, R., Vrbka, P., Edet, A., \& Goni, I. (2008). An overview of the geology and hydrogeology of Nigeria. IAH - Selected Papers on Hydrogeology Applied Groundwater Studies in Africa. doi:10.1201/9780203889497.ch11

Ajibade, A. C. (1989). Provisional Classification of the Schist Belts of North-Western Nigeria. In Kogbe, C.A. (Eds.), Geology of Nigeria (pp. 85-90). Rockview International, Jos.

Bahiru, E. A., \& Woldai, T. (2016). Integrated geological mapping approach and gold mineralization in Buhweju area, Uganda. Ore Geology Reviews, 72, 777-793.

Chandra, S., Auken, E., Maurya, P. K., Ahmed, S., \& Verma, S. K. (2019). Large Scale Mapping of Fractures and Groundwater Pathways in Crystalline Hardrock by AEM. Scientific Reports, 9(1). doi:10.1038/s41598-018-36153-1.

Conrad, J., \& Adams, S. (2007). GIS based assessment of groundwater recharge in the fractured rocks of Namaqualand, South Africa. Groundwater in Fractured Rocks, 203-217. doi:10.1201/9780203945650.ch13.

Dan-Hassan, Mohammed. (2016). ASPECT OF HYDROGEOLOGY OF THE FCT ABUJA.

Díaz-Alcaide, S., \& Martínez-Santos, P. (2019). Review: Advances in groundwater potential mapping. Hydrogeology Journal, 27(7), 2307-2324. doi:10.1007/s10040-019-02001-3.

Ejepu, J. S., Unuevho, C. I., Ako, T. A., \& Abdullahi, S. (2018). Integrated geosciences prospecting for gold mineralization in Kwakuti, North-Central Nigeria. Journal of Geology and Mining Research, 10(7), 81-94. doi:10.5897/jgmr2018.0296.

Ejepu, J., Olasehinde, P., Okhimamhe, A., \& Okunlola, I. (2017). Investigation of Hydrogeological Structures of Paiko Region, North-Central Nigeria Using Integrated Geophysical and Remote Sensing Techniques. Geosciences, 7(4), 122. doi:10.3390/geosciences7040122.

Elmahdy, S. I., \& Mohamed, M. M. (2015). Mapping of tecto-lineaments and investigate their association with earthquakes in Egypt: A hybrid approach using remote sensing data. Geomatics, Natural Hazards and Risk, 7(2), 600-619. doi:10.1080/19475705.2014.996612.

Esri Inc. (2019). ArcGIS Desktop (Version 10.5). Esri Inc. https://www.esri.com/enus/arcgis/products/arcgis-desktop/.

Ezenweani, Raymond. (2017). A Comprehensive Collation of River Basins in Nigeria: Benefits and River Basin Development Planning and Management. International Journal of Scientific and Engineering Research. Volume 8. 1587 - 1595.

Goepel, K. (2019). AHP Priority Calculator. Retrieved September 19, 2020, from https://bpmsg.com/ahp/ahpcalc.php? $=7$.

Han, L., Liu, Z., Ning, Y., \& Zhao, Z. (2018). Extraction and analysis of geological lineaments combining a DEM and remote sensing images from the northern Baoji loess area. Advances in Space Research, 62(9), 2480-2493.

Homer, C., Dewitz, J., Yang, L., Jin, S., Danielson, P., Xian, G., ... \& Megown, K. (2015). Completion of the 2011 National Land Cover Database for the conterminous United States-representing a decade of land cover change information. Photogrammetric Engineering \& Remote Sensing, 81(5), 345-354.

Hussein, A., Govindu, V., \& Nigusse, A. G. M. (2016). Evaluation of groundwater potential using geospatial techniques. Applied Water Science, 7(5), 24472461.

Kumar, P., Herath, S., Avtar, R., \& Takeuchi, K. (2016). Mapping of groundwater potential zones in Killinochi area, Sri Lanka, using GIS and remote sensing techniques. Sustainable Water Resources Management, 2(4), 419-430.

Kumar, S., Machiwal, D., \& Parmar, B. S. (2019). A parsimonious approach to delineating groundwater potential zones using geospatial modelling and multicriteria decision analysis techniques under limited data availability condition. Engineering Reports, 1(5). doi:10.1002/eng2.12073. 
Magesh, N., Chandrasekar, N., \&

Soundranayagam, J. P. (2012).

Delineation of groundwater potential zones in Theni district, Tamil Nadu, using remote sensing, GIS and MIF techniques. Geoscience Frontiers, 3(2), 189-196. doi: 10.1016/j.gsf.2011.10.007

Mogaji, K. A. (2016). Combining geophysical techniques and multi-criteria GIS-based application modelling approach for groundwater potential assessment in southwestern Nigeria. Environmental Earth Sciences, 75(16). doi:10.1007/s12665-016-5897-6.

Ngene, B. U., Nwafor, C. O., Bamigboye, G. O., Ogbiye, A. S., Ogundare, J. O., \& Akpan, V. E. (2019). Integrated water resources management in Nigeria: Implications for sustainable national development. IOP Conference Series: Materials Science and Engineering, 640, 012101. doi:10.1088/1757-899x/640/1/012101.

NiMet 2020 Seasonal Rainfall Prediction (SRP) (2020). Retrieved September 03, 2020, from

https://www.nimet.gov.ng/category/nim et-2020-srp/

Pande, C. B., Khadri, S. F. R., Moharir, K. N., \& Patode, R. S. (2017). Assessment of groundwater potential zonation of Mahesh River basin Akola and Buldhana districts, Maharashtra, India using remote sensing and GIS techniques. Sustainable Water Resources Management, 4 (4), 965-979.

Rahaman, M.A. (1988). Recent advances in the study of the Basement Complex of Nigeria. Precambrian Geology of Nigeria, Geological Survey of Nigeria Publications, 11-43.

Rukundo, E., \& Doğan, A. (2019). Dominant Influencing Factors of Groundwater Recharge Spatial Patterns in Ergene River Catchment, Turkey. Water, 11(4), 653. doi:10.3390/w11040653.
Sander, P. (2006). Lineaments in groundwater exploration: A review of applications and limitations. Hydrogeology Journal, 15(1), 71-74. doi:10.1007/s10040-0060138-9.

System of Environmental-Economic Accounting Central Framework (SEEA) (2012) White cover publication, pre-edited text subject to official editing, European Commission, Food and Agriculture Organization, International Monetary Fund, Organisation for Economic Cooperation and Development, United Nations, World Bank.

Tijani, M., Crane, E., Upton, K., Ó Dochartaigh, B.É. and Bellwood-Howard, I. (2018). Africa Groundwater Atlas: Hydrogeology of Nigeria. British Geological Survey. Accessed September 10, 2020.

Titus, R., H. Beekman, S. Adams, and L. Strachan. (2009). The basement aquifers of Southern Africa. Water Research Commission report no. TT 428-09.

Tolche, A. D. (2020). Groundwater potential mapping using geospatial techniques: A case study of Dhungeta-Ramis sub-basin, Ethiopia. Geology, Ecology, and Landscapes, $1-16$. doi:10.1080/24749508.2020.1728882.

Wirth, S., Carlier, C., Cochand, F., Hunkeler, D., \& Brunner, P. (2020). Lithological and Tectonic Control on Groundwater Contribution to Stream Discharge During Low-Flow Conditions. Water, 12(3), 821. doi:10.3390/w12030821.

Yeh, H. F., Cheng, Y. S., Lin, H. I., \& Lee, C. H. (2016). Mapping groundwater recharge potential zone using a GIS approach in Hualian River, Taiwan. Sustainable Environment Research, 26(1), 33-43. 